\title{
Utilization of Powerpoint in The Making of Nihonshi Subject Teaching Media
}

\author{
Fenny Febrianty \\ Japanese Department \\ Universitas Komputer Indonesia \\ Bandung, Indonesia \\ fenny.febrianty@email.unikom.ac.id
}

\begin{abstract}
This study aims to create a teaching media for Nihonshi subject by optimally using of Microsoft PowerPoint. This study used the Research \& Development approach. The output of this research is a visualize media teaching for Nihonshi subject. The result shows that utilization or optimally using of PowerPoint can create Nihonshi subject teaching media that can visualize the learning material so that it becomes more interesting and easily understood by students.
\end{abstract}

Keywords---Utilization, PowerPoint, Teaching Media, Nihonshi

\section{INTRODUCTION}

Utilization of PowerPoint in making of Nihonshi subject teaching media means optimally using of PowerPoint as a computer program to create teaching media for Nihonshi (Japan History) subject.

PowerPoint is a powerful and ubiquitous communications technology and aid to teaching and business presentations [1]. Nowadays, PowerPoint is an educational tool for teaching and delivering materials in classes was basically developed for presentation and not essentially for teaching and learning in a classroom only. Its applications in teaching and learning settings should provide better means of communicating information to the students [2]. The use of technology can have a very positive influence on learning, provided that its use fits the circumstances inherent in learning[3].

In middle and high school classrooms, teaching history and social studies as one has been taught typically featuring lectures by the teacher, whole class discussions, memorization of facts, content drawn primarily from text-book [4]. Nihonshi as one of many subjects in my institution also tend to be narrative based on time or cause and effect relationships that are full of event names, times of occurrence of events, names of places, names of characters, and various terms are used according to the time. For most students this is not immediately understood or remembered. Students need thinking stages so that the transfer of knowledge by lecturers can be accepted. One of the tools that can help the process of knowledge transfer goes better in teaching and learning activities is the teaching media.

Teaching media is every tool both software and hardware that is used as a medium of communication and aims to improve the effectiveness of the teaching and learning process [5]. Teaching media can enhance students' learning process in teaching which in turn is expected to enhance the learning outcomes they achieve. In the field of education, the use of PowerPoint or more commonly referred to as PowerPoint as a medium of teaching is not new [6].

PowerPoint as a program consists of several visual elements consisting of slides, text, images, and color fields that can be combined with the background that is already available. Controlling the operation can be made without motion, or made with certain movements as desired. The entire display can be adjusted as needed, whether it is running alone according to the desired timing or running manually, using the mouse [7]. Through PowerPoint text, colors, images, and animations can be created as needed to attract students' attention so that the teaching and learning process can run properly.

In class of Nihonshi subject, the author uses lecture method with PowerPoint media. However, the teaching media that is made is still very simple which used text and color features, Insert Picture, and SmartArt only. Meanwhile, most of the material in the Nihonshi subjek is considered to be more effective if it can be delivered in the form of visualization.

This study aims to optimize the features in PowerPoint in making of Nihonshi subject teaching media which is limited to create a media that can visualize teaching material about origin of the Japanese people.

\section{METHODS}

This study used the Research \& Development approach. The procedure to create PowerPoint media as follows:

a. Program identification, this is intended to see the suitability between programs made with material, goals (students), especially abilities, age and education level. It is also necessary to identify the availability of supporting resources such as images, animations, videos, etc;

b. Gather supports materials according to material and targets needs such as video, images, animation, sound. Collection of these materials by searching through the internet, using those already in your directory, producing materials for example for video needs, shooting and image needs through scanning images. At the same time, the preparation of material taken from the main material, for example books, modules, complete papers. Material 
for PowerPoint should be packaged into short descriptions, subject points or pointers.

c. After the material has been collected and the material has been summarized, then the work process in Powerpoint is complete. Then change the final result in the form of Slide Show, Web Pages, or Executable File (exe);

d. After the program is finished, it is not immediately used, it is better to review the program in terms of language, text, layout, and truth concept, then revised and ready for use [8].

\section{RESULT AND DISCUSSION}

In order to be able to visualize the material, the PowerPoint can be used optimally which means using all available features. The tips for making media by using PowerPoint as follows:

a. Use a simple, contrasting and consistent background, avoid complicated, annoying and full backgrounds;

b. Use consistent, simple and clear letters like Arial, Verdana, Tahoma and Trubucet, don't use complicated and continuous letters;

c. Visualize your message, do not use writing unless forced;

d. Maximize PowerPoint features like image, video, animation and sound elements, but don't overdo it;

e. Create your own background or template to increase the attractiveness of the presentation and clarify the message;

f. If you use a background with bright colors, then use text with dark intensity, and vice versa;

g. Use colors to enhance the appearance while focusing on the presentation. But not too much because it will seem crowded and disrupt the presentation of material. Use contrasting colors or matching colors;

h. Avoid more than 3 color combinations in one slide;

i. Use letters that have clear and firm characters, such as Arial, Tahoma or Verdana, avoid characters or types of decorative fonts because they are more difficult to read;

j. The letter size is at least 24 for sentences and 40 for titles;

k. Maximum 6 sentences and 25 words in one slide;

1. Use powerful words [8][9].

Based on the above requirements the author create the media with the following results as shown in Fig.1 to Fig. 9 below:

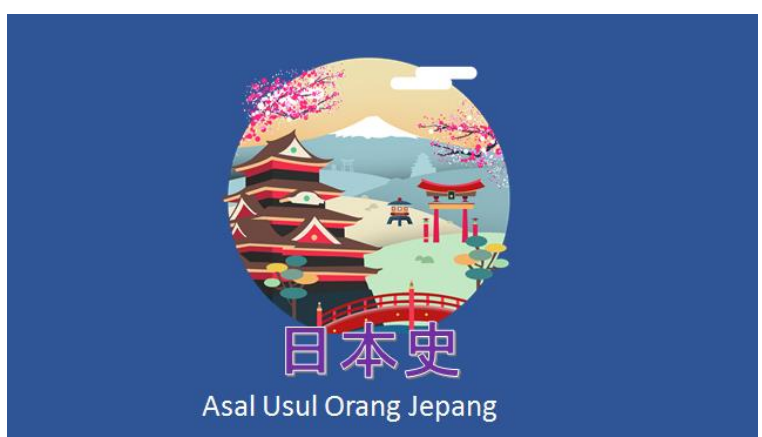

Fig. 1. History of japanese

Fig. 1 is the history of japanese. All slides is made simple, contrasting, and use consistent backgroud [8].



Fig. 2. Formation of Japan

Fig. 2 is a slide that visualizes the formation of Japan archipelago from the last 10,000 years as we know it today. Consists of four main islands, namely Honshu, Kyushu, Shikoku, and Hokkaido.

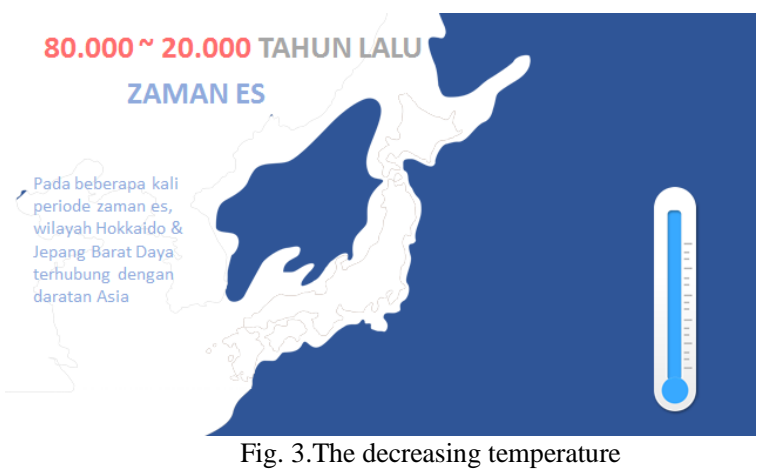

Fig. 3 is a slide that visualizes the decreasing temperature of the earth's surface that caused the ice age. As a result the mainland of Japan is connected with mainland Asia.

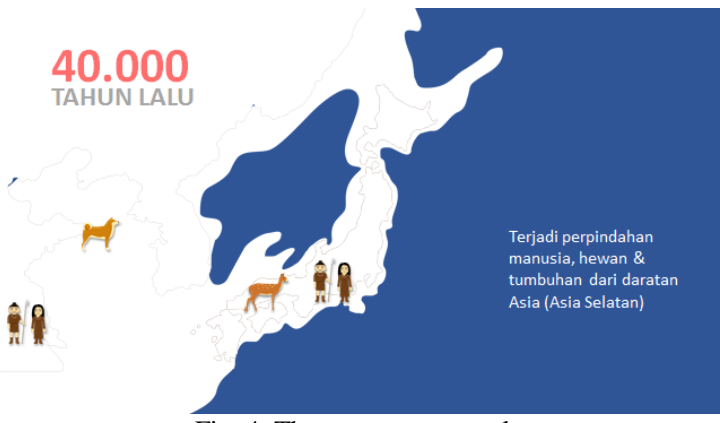

Fig. 4. The movement people

Fig. 4 is a slide that visualizes the movement of people from mainland Asia to mainland Japan.

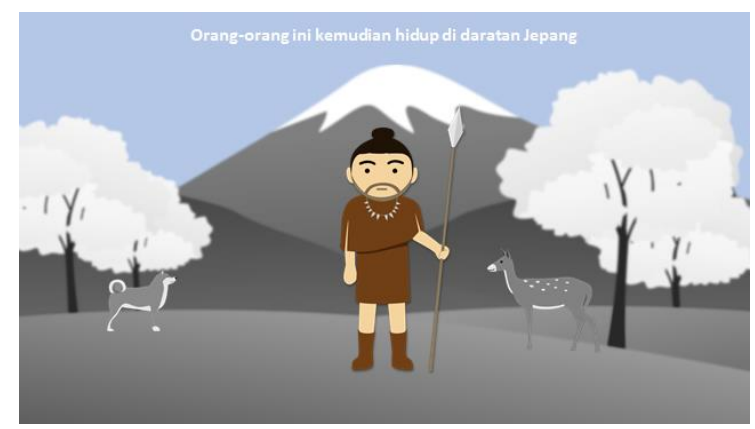

Fig. 5. Showing of slide 5

Fig. 5 is a slide that visualizes the figure of people from mainland Asia who entered mainland Japan and settled there. 
From archaeological evidence it is estimated that they are from the South Asian region.

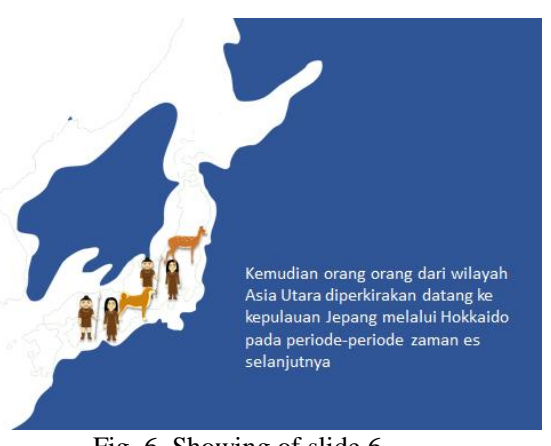

Fig. 6. Showing of slide 6

Figure. 6 is a slide that visualizes the end of the ice age. People who are 'trapped' on the Japan mainland lead lives from generation to generation. After some time there was another ice age which made the Japanese land reconnected to mainland Asia. During this time people from mainland Asia re-entered and settled on the Japan mainland. They are predicted came from the North Asia region.

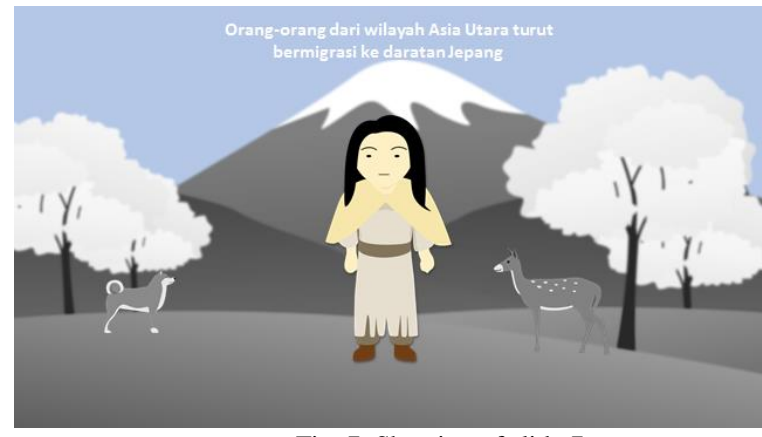

Fig. 7. Showing of slide 7

Fig.7 is a slide that visualizes the figure of people from North Asia who entered and settled in Japan.

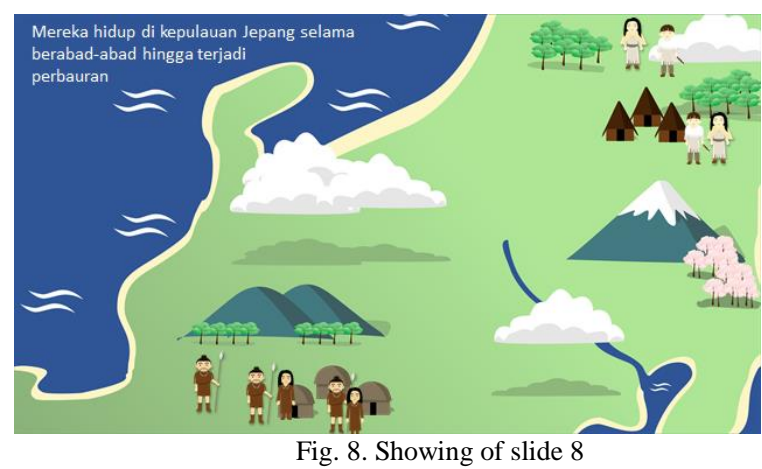

Fig. 8 is a slide that visualizes the lives of people from North Asia and South Asia who were 'trapped' on the Japan mainland when the last ice age ended. They live separately with their groups. And then there is interaction between groups These people later became the forerunners of Japanese ancestors.

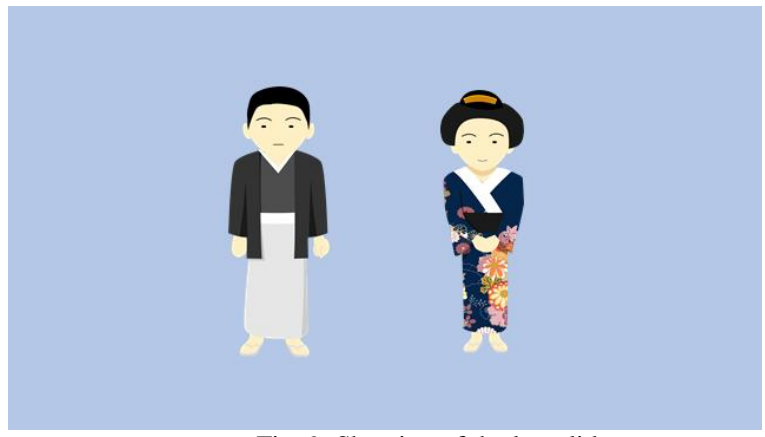

Fig. 9. Showing of the last slide

Figure. 9 is a closing slide that describes the current Japan generation as a result of mixing with other nations in Asia, especially China and Korea from generation to generation in a very long period of time.

Multimedia learning promotes acquisition, retention, and transfer (application) of information [10]. Many learning outcomes using PowerPoint get better results. This is caused by the use of PowerPoint programs as learning media which has several advantages in terms of material presentation such as color, letters and animation, both text animation and animated images or photos as high as will stimulate students to know more far information about the teaching materials presented [6].

To find out the response to the media, author asks for opinions from 30 students who had previously attended the Nihonshi course through questionnaire technique. The questionnaire results show that 80 percent of students stated that the media more interesting and made students easier to understand and remember the material presented because it was displayed in the form of visualization through animation [11].

The material about the origin of Japan people in the form of visualization is expected to facilitate students in absorbing information and remembering it. The use of cartoon models is also expected to give the impression of 'entertainment' for students even though the material presented is actually serious. This is expected to maximize the transfer of knowledge both in the form of logic and physically from the lecturer to the student in this course.

This is because of cognitive theory of learning is activated through five steps: "(a) selecting relevant words for processing in verbal working memory, (b) selecting relevant images for processing in visual working memory, (c) organizing selected words into a verbal mental model, (d) organizing selected images into a visual mental model, and (e) integrating verbal and visual representations as well as prior knowledge [10].

The author notes that the thing that still needs to be improved and developed in the media that has been made for the future is the improvement of the concept. This is because there are multi-interpretive or ambiguous visualizations. For a while this can be anticipated by the explanation of the lecturer, to avoid mistakes in receiving knowledge from the material presented. But, this is very likely to be developed for the future because PowerPoint slides are easy to update and can be provided excellent opportunity for creating electronic handouts, and these handouts can be linked to World Wide Web pages from where the students can download them, print them, or revisit them if they need [12]. 


\section{CONCLUSION}

Utilization of PowerPoint on the making of Nihonshi subject teaching madia is done by maximizing the using of animation features with Corel Draw program support that is able to create media that can visualize learning material so that its becomes more interesting and easy to understood and remember by students.

\section{ACKNOWLEDGEMENTS}

We acknowledge the partial financial support of this reseach from LPPM Directorate (Directorate of Research and Community Services) of Universitas Komputer Indonesia.

\section{REFERENCES}

[1] Craig, R.J. \& Amernic, J.H. "PowerPoint Presentation Technology and the Dynamics of Teaching", in Innov High Educ (2006) 31: 147 https://doi.org/10.1007/s10755-006-9017-5

[2] M.Hashemi, M. Azizinezhod, and M. Farokhi, "PowerPoint as an Innovative tool for teaching and learning in modern classes", in Procedia Social and Behavioral Sciences 31, 2012, pp 559-563.

[3] Cladellas Pros, Ramon [et al.]. "Effects of the PowerPoint methodology on content learning. "Intangible capital", Abril 2013, vol. 9, núm. 1, p. 184-198.

[4] Maloy R.W. and LaRoche.I., "Student-Centered Teaching Methods in the History Classroom: Ideas, Issues, and Insights for New Teachers", in Social Studies Research and Practice http://www.socstrp.org

[5] Rumumpuk, DB. (1988). Media Instruksional. Jakarta : Ditjen Pendidikan Tinggi Depdikbud

[6] Sudjana, Nana.2006. Penilaian Hasil Proses Belajar Mengajar, Bandung: Remaja Rosdakarya

[7] Andi.2007.Panduan Praktis Microsoft 2007, Semarang: Wahana Komputer

[8] Nurseto,Tejo.2011. Membuat Media Pembelajaran Yang Menarik. Jurnal Ekonomi \& Pendidikan Vol 8 (1), 19-35

[9] Ruffini, M. F. (2009). Creating animations in PowerPoint to support student learning and engagement. EDUCAUSE Quarterly, 32(4), 1-4

[10] Berk, R. A. (2011). Research on PowerPoint ${ }^{\circledR}$ : From basic features to multimedia. International Journal of Technology in Teaching and Learning, 7(1), 24-35.

[11] A.B. Ronald, "Top 10 Evidence-Based, Best Practices for PowerPoint ${ }^{\circledR}$ in the Classroom", Transformative Dialogues: Teaching \& Learning Journal Volume 5 Issue 3 April 2012

[12] A.Szaboa,N.Hastings, "Using IT in the undergraduate classroom: should we replace the blackboard with PowerPoint?" in PERGAMON Computers \& Education 35 (2000) 175-187. 